\title{
Evolution of the Family: Theory and Implications for Economics*
}

\author{
Ingela Alger ${ }^{\dagger}$ and Donald Cox
}

July $3,2019^{\S}$

\section{Summary}

Which parent can be expected to be more altruistic toward their child, the mother or father? All else equal, can we expect older generation members to be more solicitous of younger family members or vice versa? Policy interventions often target recipients by demographic status: more money being put in the hands of mothers, say, or transfers of income from young to old via public pensions. Economics makes predictions about pecuniary incentives and behaviour, but tends to be agnostic about how, say, a post-menopausal grandmother might behave, just because she is a post-menopausal grandmother. Evolutionary theory fills this gap by analysing how preferences of family members emerge from the Darwinian exigencies of "survive and reproduce." Coin of the realm is so-called "inclusive fitness," reproductive success of oneself plus that of relatives, weighted by closeness of the relationship. Appending basic biological traits onto considerations of inclusive fitness generates predictions about preferences of family members. A post-menopausal grandmother with a daughter just starting a family is predicted to care more about her daughter than the daughter cares about her, for example. Evolutionary theory predicts that mothers tend to be more altruistic toward children than fathers, and that close relatives would be inclined to provide more support to one another than distant relatives. An original case study is provided, which explains the puzzle of diverging marriage rates by education in terms of heterogeneity in preferences for commitment. Economists are justifiably loathe to invoke preferences to explain trends, since preference-based explanations can be concocted to explain just about anything. But the evolutionary approach does not permit just any invocation of preferences. The dictates of "survive and reproduce" sharply circumscribe the kinds of preference-related arguments that are admissible.

Keywords: family economics, evolution, Hamilton's rule, biology, marital outcomes

\footnotetext{
* Acknowledgments Ingela Alger acknowledges funding from the European Research Council (ERC) under the European Union's Horizon 2020 research and innovation programme (grant agreement No 789111 - ERC EvolvingEconomics), and IAST funding from the French National Research Agency (ANR) under the Investments for the Future (Investissements d'Avenir) program, grant ANR-17-EURE0010.

${ }^{\dagger}$ Toulouse School of Economics, CNRS UMR5314, University of Toulouse Capitole, and Institute for Advanced Study in Toulouse, France. ingela.alger@tse-fr.eu

^Boston College, Chestnut Hill, USA. donald.cox@bc.edu

$\S$ This is a draft of an article that was subsequently accepted for publication by the Oxford Research Encyclopedia in Economics and Finance. DOI:10.1093/acrefore/9780190625979.013.439
} 


\section{Evolution and family member priorities}

The evolutionary approach to the family is concerned with the interests and preferences of individuals seeking to form families and of family members-fathers versus mothers, grandmothers versus granddaughters, close versus distant kin. It complements the economic approach by asking how preferences came to be rather than taking them as given. Economists opt for parsimony by inferring preferences from choices influenced by prices and incomes. In contrast, the evolutionary agenda is concerned with predicting, say, the altruism of mothers versus fathers or parents versus children.

There are several trends in family behaviour that can arguably be ascribed to gender or age differences in preferences, and evolutionary thinking can help explain and predict these differences. Most studies of allocation of consumption in households, for instance, show that children do better when mothers are given more control over household expenditures (e.g., Lundberg, Pollak, and Wales, 1997). Accounts of private transfers over the life-cycle show that more money usually flows from older to younger family members rather than vice-versa (Lee and Mason, 2011). Studies of family formation show that men and women place different weights on traits like looks and earning potential in evaluating a marriage partner (e.g., Fisman et al., 2006). Bequest data indicate that closer relatives receive larger inheritances (Hartung et al., 1976).

Incomes and prices are capable of explaining only a portion of these findings. Family behaviour differs by characteristics like gender, age and relatedness, even controlling for pecuniary influences. The goal of the evolutionary approach is to understand how and why the preferences of family members came to be the way they are. 


\section{The Family: Variation Across Taxa, Space, and Time}

The human family is somewhat of an outlier in the animal kingdom. To wit, in many fish species the female leaves her eggs behind, and sometimes the male who fertilizes them stays around to protect them against predators. In pipefishes and seahorses (family Syngnathidae) such protection by the male is quite extreme, since he undergoes "pregnancy" by gestating embryos in a special broodpouch. Families of our primate relatives are also quite different from our own (Kappeler and van Schaik, 2002). Among chimpanzees, females often mate with several males, and males do not provide direct care to offspring, which nonetheless benefit from the protection that males confer on the group to which they belong. Like chimpanzees, bonobos also live in large groups, but contrary to chimpanzees, among the bonobos the group leaders are female. Gorillas have yet another type of family: some adult males monopolize sexual access to a harem of females, and often such lucky males live alone with their females and their joint offspring.

Comparison of our own species to other species reveals that there is a surprisingly high degree of variation within our species - across both space and time. Systematic differences between the family systems in use in different parts of the world have been documented in great detail by anthropologists and demographers, who have collected first-hand observations of the characteristics of family systems in hundreds of societies; see, in particular, Murdock's Ethnographic Atlas (Gray, 1998), and the comparative studies of Goody (1976) and Todd (2011). For example, some family systems are patrilineal while others are matrilineal. In most places males live together with their mate(s), but in some places they continue living with their mothers and sisters while paying essentially only nocturnal visits to their mates (He et al., 2016). Polygyny rates differ between traditional societies. In modern societies, polygynous marriage is sometimes allowed (e.g., Indonesia, Kenya), but more often than not, monogamy is imposed by law (Zeitzen, 2008). The work of historians, based on written accounts by contemporaries, further reveals that relations within the family in Europe have changed dramatically since classical 
antiquity (Scheidel, 2008). Thus, ancient Greek men spent little time with their wives; they didn't even share meals with them. Men were free to consort with prostitutes and take concubines. Either spouse could easily initiate divorce. Fathers got custody of the children. Preschool children were brought up by male tutors. Children of both sexes were often treated as sex objects. There was no well-defined concept of child abuse. Familial mores in ancient Rome were similar. Infanticide was also common, and children were often sold or abandoned. As with Greece, fathers were given child custody in case of divorce. Recently, genetic data has provided researchers with a new tool to peek into the past. In particular, analyses of distributions of variants of the male-specific Y-chromosome can be used to infer the effective rates of polygynous mating in the past; such studies confirm that these rates have fluctuated across time and space (Rasteiro, and Chikhi, 2013, Balaresque et al., 2015).

Notwithstanding the variation in human family systems across space and time, anthropologists have also identified a certain number of features which are common to most societies. In particular

"Human life histories, as compared to those of other primates and mammals, have at least four distinctive characteristics: an exceptionally long lifespan, an extended period of juvenile dependence, support of reproduction by older post-reproductive individuals, and male support of reproduction through the provisioning of females and their offspring.” (Kaplan et al., 2000)

and 
"Social organization among human foragers is characterized by a three-generational system of resource provisioning within families, long-term pair-bonding between men and women, high levels of cooperation between kin and non-kin, and relatively egalitarian social relationships.” (Kaplan, Hooper, and Gurven, 2009).

What are the drivers of these family formation patterns and intra-family behaviours across time and space? Are pecuniary forces the key drivers, or do evolutionary forces instead play the more important role? If it is a mix of both, do pecuniary forces govern a specific subset of the features that characterize families? If so, which ones? Answers to these questions are arguably crucial for policy-makers to design effective policies. While such answers do not yet exist, a productive way forward may be to increasingly include evolutionary thinking in the economics literature.

\section{Evolutionary Logic: Survive and Reproduce}

At the core of the evolutionary approach is the concept of "survive and reproduce" -i.e., fitness. Not everyone survives to maturity, and not all survivors leave descendants. Those with traits that promote survival and reproduction possess an evolutionary edge. To the extent that descendants inherit those traits-biologically or culturally-they will possess that edge as well. The proclivities embedded in our utility functions have been shaped over the millennia and vetted by selection. Our tastes and attitudes can thus be thought of as adaptations, that is, characteristics suited for survival and reproduction. Think of taste buds, which evolved to steer us toward nutritious food and away from low quality foods or toxins. People coping with food insecurity rely on their sense of taste for survival. It is instructive to recognize that what was once adaptive 
can turn problematic, as in having tastes for fats and sweets that lead to obesity and other health problems. Which leads to the next point.

\section{What Evolution Isn't}

We don't have to like or accept evolutionary outcomes. (Natural selection notwithstanding, people can choose not to have children, for example.) Just because something is "natural," as in natural selection, does not mean that it is necessarily good or even excusable. Calling infidelity an "evolved mating strategy" does not make the behaviour less reprehensible or get the cheating spouse off the hook. Biology is not destiny. Except in cases like the disease Huntington's Chorea, genetically based proclivities leave plenty of room for individual choice and social influences. Further, evolution doesn't obviate choice. Incentives and social forces obviously matter for behaviour as well.

For instance, fertility falls short of maximizing the number of grandchildren, likely because cultural forces overwhelm heritable fecundity (Bergstrom, 1996). Economic forces like wages and wealth guide choices concerning number of children versus investments per child (Becker and Lewis, 1973). Biology is an adjunct, and complement, to these forces. Evolved concerns about reproductive success are but one of several behavioural forces. Nonetheless, disregarding them may result in misleading conclusions.

\section{Hamilton's Rule, and Five Applications to Economics}

Evolved traits facilitate reproductive success. If traits are biologically transmitted, then reproductive success subsumes not just direct offspring and their descendants but more distant relatives such as nieces and nephews, albeit with less weight than for children. The weights are 
so-called coefficients of relatedness, $r$ : the chances a given gene for a pair of individuals would have been inherited from a common ancestor. ${ }^{4}$

William Hamilton (1964) derived the logic of assistance between relatives. I will help you if the costs, $C$, to my reproductive success, or fitness, are less than the benefits, $B$, to your fitness, down-weighted by your relatedness to me, $r:^{5}$

$$
r B>C \text {. }
$$

So-called "Hamilton's Rule" forms a basis for predictions about preferences and interests of family members. In the 1950's, anticipating Hamilton's insight, biologist J.B.S. Haldane is thought to have claimed that while he wouldn't jump into the river to save his brother, he would jump in to save two brothers or eight cousins. To elaborate on Haldane's intuition, imagine that my son and I are soldiers and a sniper is aiming a grenade launcher at him. I can cry out, drawing deadly fire toward myself but saving him. The stakes? Consider a special allele implicated in altruistic behaviour. There's a 50 percent chance that my son inherited my gene. But since I have that same gene with certainty, it is in the allele's best interest to impel me to keep still. ${ }^{6}$

But now suppose that, though I'm unable to have more children, I expect my son to produce three children in the future. Each of them will have a 25 percent chance of inheriting my gene. Now I save 4 lives by sacrificing myself. Weighting by relatedness yields $.5+3 \times .25=1.25$, which exceeds the cost I incur by sacrificing my life. ${ }^{7}$ While the 'sterile soldier' example is contrived, it parallels a more realistic case, whereby sterility lowers a post-menopausal woman's cost of sacrifice.

Appending biological exigencies (such as being young versus old) onto concerns about extended fitness generates even finer predictions about the family members' preferences. An older parent might be more altruistic toward a child nearing reproductive prime than vice versa. 
Age is just one example of a basic biological attribute that impinges on the benefits and costs of familial help. There are many others.

For instance, producing offspring exacts a much bigger physical and mental toll on mothers than on fathers, which could create differences in preferred quality-quantity trade-offs in reproduction. Another example: Parents are more closely related to-and more altruistic totheir children than to their nieces and nephews. They can be expected to bequeath more to their children than to more distant relatives. ${ }^{8}$

The remainder of this section describes some predictions emanating from Hamilton's rule and establishes links between these predictions and economics.

\section{Altruism Towards Parents and Children: Inter-Generational Transfers}

Are parents more altruistic toward children than vice versa? This question of preferences matters for resource flows between generations. For instance, members of the large and growing "Sandwich Generation" are responsible for both children and dependent elderly. How they can be expected to allocate their time depends partly on the strength of altruism toward younger versus older family members. Further, the relative strength of altruism between generations likely matters for economic growth. Transfers from old to young, in the form of parental expenditures for education or help with early career living expenses facilitate human capital investment.

How might such preferences be expected to lean? Hamilton's rule predicts that altruism from older to younger would predominate, as the example of menopause illustrates. All else equal, help from a post-menopausal mother to a daughter on the brink of starting a family is likely to enhance inclusive fitness to a greater degree than help flowing in the opposite direction.

Such age asymmetries in altruism can be assessed by comparing grief experienced at the loss of a family member. Survey instruments like the one developed by Sanders (1980) assess 
problems with, inter alia appetite, sleep, concentration, motivation, self-confidence and health. Sanders (1980) finds that grief experienced by parents at the loss of a child is far stronger than the reverse. Further, Owen, Fulton, and Markusen (1983) find that grief symptoms last much longer when parents lose a child.

But are the data on transfers consistent with the prediction? Inter-generational transfer patterns in small-scale hunter-gatherer societies are arguably indicative of the ancestral roots of family behaviour. Kaplan (1994) uses painstakingly gathered data on calories produced and consumed by age, and found that resources flow from old to young. Grandparents were net contributors to the family right up to the end of life.

Although patterns are more complex in modern societies, Ronald Lee and Andrew Mason find that private transfers are in line with the prediction in that they tend to flow from old to young in a cross-section of 59 countries (Lee and Mason, 2011). But these patterns are not necessarily informative about altruistic preferences since inter-generational income differences could explain these trends as well. Older family members have more job market experience and access to capital markets compared to younger people still in school or just starting work.

In some countries, private transfers from young to old predominate, a seeming contradiction of Hamilton's rule. For instance, the Vietnam Living Standards Survey indicates that transfers from adult children to parents are about double those from parents to children (Cox, 2004). Lei et al. (2012) find that for elderly Chinese transfers received from adult children exceed transfers given to children and comprise 15 percent of elders' pre-transfer household income. Interestingly, Lei et al. (2012) cite culture - the oft-mentioned Confucian "filial piety" that characterizes Chinese family values - as an important driving force. One interpretation is that humanly devised cultural or religious rules are sometimes necessary for individuals to adopt behaviours which go against natural inclinations. The fact that guidelines for treatment of parents are salient in JudeoChristian culture ("Honor thy father and thy mother") and in Islam (several Koranic verses on the 
treatment of parents), but that no such salient guidelines are provided for treatment of children, is in line with this interpretation.

But why would such cultural rules for elderly care evolve at all? One answer is that the elderly embody knowledge. Diamond (1997) shows that an elder person's long-term memory can help the family and even the entire village. Imagine three types of plants: edible, barely edible, and poisonous. A cyclone wipes out most edible plants. The barely edible plants can get you through the famine, but hardly anyone remembers which ones they are since no one has eaten them since the last cyclone several decades earlier. And no one wants to experiment because of the risk of poisoning. An elderly woman in the village remembers the last cyclone and points out the plants that can be eaten without risk of poisoning. Likewise, elders in traditional agricultural families can provide farm-specific knowledge and experience for coping with adversity (Rosenzweig and Wolpin, 1985). Indeed, Wing (1995) argues that filial piety, the central tenet of Confucianism, arose to facilitate the transmission of location-specific knowledge from older to younger generations. Norms of filial piety facilitate the provision of farm-specific knowledge and experience in exchange for old-age support. ${ }^{9}$

Another answer is that old-age support facilitates allomothering, that is, infant care provided by someone besides the mother. Allomothering plays a key aspect in the social life of humans. Birth intervals in natural fertility populations are about 3 years, compared to 4-5 years for chimpanzees (Sear and Mace, 2008). On top of that, humans are born altricial, that is, in need of complete support from others for an extended period of time. It takes a human one year to be able to walk; it takes a chimpanzee one month. It takes a chimpanzee 7 months to develop an adultsized brain; it takes a human until late adolescence or even beyond. Keeping grandparents alive therefore redounds to the benefit of the very young - essentially an indirect transfer from adult children of the elderly to their own children. Evidence supporting this hypothesis is provided by Sear and Mace (2008), who review a large number of studies of kin availability on child survival. 
The studies are focused on traditional societies and historical case studies. They find that the loss of a grandmother negatively affects child survival (in seventy percent of the cases for maternal grandmothers, and a little over 50 percent for paternal grandmothers). In economics, the study by Esther Duflo (2003) is telling. In the early 1990's the South African government dramatically increased pensions for the poor elderly. Because there are many multigenerational households in South Africa it was possible to investigate whether the increase in grandparental income affected the nutrition of grandchildren. Duflo (2003) found that the pension increase benefited a subset of grandchildren: girls living with maternal grandmothers had improvements in weight for height and height for age.

Evolutionary theory and findings from hunter-gatherer societies suggest that deep-rooted preferences favour net resource transfers from old to young. But in many countries cultural and religious rules sustain large transfers from adult children to their parents. To what extent will these rules survive the dramatic changes brought about by economic development? Some evidence suggests that they may be quite robust. For example, Vietnam's rapid growth did little to alter this pattern. The same is true for Taiwan (Lee, Parish, and Willis, 1994). Arguably, closer examination of these developments would constitute a valuable contribution to the growing literature in economics on the persistence of cultural traits.

\section{Maternal Versus Paternal Altruism: The Gender Wage Gap, Savings, and More}

Is there a biological case for maternal/paternal differences in preferences for offspring care? Imagine a couple with an infant. Each spouse faces a trade-off between investing in the child and seeking additional mates. An additional mate would enhance prospective reproductive success more for the father, which increases his opportunity cost of providing care. If being tempted by 
additional mates resulted in more surviving offspring for males, such preferences would be adaptive, or fitness enhancing (see Eswaran and Kotwal, 2004).

One reason the question matters for economics of the family is that, despite advances in education and the market for women's work in developed countries, the gender pay gap in developed countries has not improved commensurately. Child bearing is emerging as the final barrier to gender wage parity (Bertrand, Kamenica, and Pan, 2015, Kleven, Landais, and Sgaard, 2018). For reasons not well known, mothers, but not fathers, lose ground in their careers once they have children. Perhaps mothers face discrimination via "mommy tracking." Alternatively, mothers may be more inclined to care for children for reasons that have to do with preferences, driven perhaps by social norms, biologically based preferences or both.

With respect to male preferences, there is evidence that men are indeed inclined to seek additional mates when given the opportunity. Bethmann and Kvasnicka (2013) find that shortages of men caused by military casualties in Bavaria during World War II caused a large increase in out-of-wedlock fertility. Willis's (1999) theory of fatherhood explicitly incorporates male preferences for additional mates to address the problem of male shortages in the inner city and out-of-wedlock fertility. Angrist (2002) finds lower marriage rates, and worse child outcomes, among immigrant cohorts with shortages of men.

In contrast, scarcity of women appears to be associated with increased male investment in children. For example, Wei and Zhang (2011) find that, in the wake of sex ratio imbalances created by China's one-child policy, much of China's rise in savings is fueled by parents seeking to attract a spouse for their son. To the extent that this wealth allocated to children, female shortages indirectly encourage investment in children.

When men are scarce and hence wield more bargaining power, their preferences appear more likely to hold sway. Those preferences tilt away from the nuclear family toward reproduction 
with multiple mates. When women are scarce, outcomes tend toward increases in male investments in children.

Further, there is overwhelming evidence from studies of household allocation that putting more money in the hands of mothers tends to improve outcomes for children. For instance, in the late 1970's the U.K. changed the way its child benefit was administered. Instead of a reduction in taxes withheld from the father's paycheck, a cash payment was made to the mother. Lundberg, Pollak, and Wales (1997) found large increase in spending for children's (and women's) clothing following the policy change. This is but one example of dozens of studies for both rich and poor countries documenting that children gain when mothers are empowered. ${ }^{10} \mathrm{~A}$ related striking finding appears in Sear and Mace's (2008) survey: while the death of the mother always hurts the prospects for child survival, the death of the father does so in only one-third of the studies.

Of course, maternal-paternal differences in altruism need not have much to do with biology. They could, for instance, emanate from cultural and social forces. Yet there is emerging prima facie evidence that hormonal mechanisms implicated in child care differ between mothers and fathers. ${ }^{11}$ The main hormonal response to childbirth for mothers is production of oxytocin, which is associated with bonding. The main response for fathers is the production of vasopressin, which is associated with vigilance. New fathers also experience a decrease in testosterone, which is associated with preference for additional mates.

\section{Mate Guarding: Paternal Investment, and Female Labour Market Participation}

Another biological difference that in principle has implications for parental altruism is certainty of relatedness to offspring. A woman is certain or her relatedness to a newborn, barring extraordinary events like babies being switched in the maternity ward. ${ }^{12}$ But a man, at least in principle, might experience a flicker of doubt and diminished altruism as a result. 
Recent DNA-based evidence suggests that rates of misattributed paternity vary dramatically by subsample (e.g., paternity testing labs versus representative samples) but its incidence is probably low overall. Anderson (2006) organizes studies according to whether paternity confidence is likely to be high (e.g., descendants of Jewish priests (Kohanim)), low (e.g., a paternity testing laboratory), or unknown. He reports a median of 1.9 percent non-paternity among the high-paternity-confidence studies and a median of 30.5 percent among the lowconfidence ones.

Perceptions of paternity confidence arguably matter as much as facts, but evidence is scarce. One estimate comes from Anderson, Kaplan, and Lancaster (2007) who had self-reports about paternity confidence from a sample of men living in Albuquerque, New Mexico. In response to a question about pregnancies attributed to them, men reported less-than-certain expectations that they were the father in 1.46 percent of the cases.

Notwithstanding the low rates of misattributed paternity, the evolutionary perspective on marriage and other long-term relationships is that they are, inter alia, a means of protecting reproductive interests by facilitating “mate guarding," whereby spouses monitor one another's fidelity. The standard treatment posits that the husbands are concerned about paternity uncertainty and wives are concerned about resources diverted to outside mating opportunities (Buss, 2002).

Differing costs of infidelity for husbands versus wives gives rise to the infamous "double standard" whereby female infidelity is punished more heavily and guarded against more intensely (Geary, Vigil, and Byrd-Craven, 2004, Bethmann and Kvasnicka, 2011). A philandering husband invests less in his wife's children. An unfaithful wife who produces a child her husband thinks is his, but is not, can exact an enormous toll on his fitness. Hence female infidelity is punished more heavily and guarded more intensely, in the form of restrictions in rights, sequestering, 
chaperoning, work regulations, and so forth. In extreme form, such guarding can be injurious to health and well-being or even life threatening as in the case of female genital mutilation.

For instance, female circumcision has been interpreted as an attempt to discourage female infidelity by reducing sexual pleasure, and domestic violence a weapon wielded by husbands for controlling the social lives of their spouses. Thus, mate guarding is implicated in extensive, worldwide public health problems. The World Health Organization, for example, estimates that between 100 and 140 million women and girls in 28 countries have experienced some form of genital mutilation, including clitoridectomy (removal of the entire clitoris) and infibulation (sewing the vagina shut in order to insure virginity).

Evolutionary psychologists argue that jealousy is an emotion intimately related to mate guarding, and sex differences in mate guarding concerns have been found to play out with respect to corresponding differences in how jealousy is experienced. Buss et al. (1992) find that male jealousy tends to be triggered by the prospect of sexual infidelity on the part of their mate, whereas female jealousy tends to be ignited by emotional infidelity, that is, the prospect that their mate is cultivating serious romantic involvement elsewhere. This accords with sex differences in the costs of infidelity: while the worst-case scenario for the male is misattributed paternity, the worst-case scenario for the female is desertion.

Why would mate guarding practices figure into economics of the family? Arguably, they should be expected to matter significantly, since they should have a first-order impact on women's ability to undertake activities outside the home on their own. As such, they may be expected to be a crucial determinant of any female involvement in market exchange, including working outside the home, undertaking entrepreneurial activities, or simply going to the market. Recent data collected in India by Bernhardt et al. (2018) on men's and women's preferences are in line with this hypothesis. They find that men are more likely than women to be opposed to 
women's work outside the home. Moreover, they detect a significant correlation between the stated preferences and actual female labour supply.

\section{Preferences for Prospective Mates-Sexual Selection and Conspicuous Consumption}

Searching for a partner requires judging prospective mates plus creating a favourable impression of oneself. Reproductive concerns plus biological basics predict sex differences in what people look for in a mate. Evidence from online dating services offers a window into sex differences in preferences. Hitsch, Hortaçsu, and Ariely (2010) look at users of an online dating service and find that women are more selective - they contact fewer men than vice versa. Further, women place relatively more weight on income and occupation relative to appearances. Fisman et al. (2006) conducted an experiment in Speed Dating, whereby subjects were randomly paired. They found that men were more responsive to physical attractiveness while women showed a preference for men raised in affluent neighbourhoods. Buss (1989) collected survey information from 37 cultures on 6 continents. They found that in 36 of the 37 surveys, women placed a higher value on a man's financial and career prospects while men placed higher value on youth and good looks.

While these patterns could well be driven by cultural norms, they are consistent with considerations of reproductive capabilities, search for mates and parenting (Trivers, 1972). According to Trivers' theory, the sex that invests more in offspring has more to lose from a poor match, and therefore will be the choosier one, and the sex that invests less competes for the sex that invests more.

Some evolutionary psychologists (e.g., Miller, 2000) argue that competition for mates spurs males to signal their value via sports, artistic endeavours, wealth displays and the like. Status competition among males would likely reward risk-taking. Indeed, males tend to be more risk- 
loving than females (Croson and Gneezy, 2009) (though there are several possible explanations for this, including culture-based ones). Relatedly, Edlund (2018) argues that marriage arrangements that deny women the freedom to choose their spouses reduces the status of women to male property and diminishes male incentives to excel in ways that make them desirable as mates, which in turn could diminish economic growth.

An evolved taste for status can also be expressed in the form of conspicuous consumption (Eaton and Eswaran, 2003). A quick way to signal wealth, for instance, would be to wear a luxury Swiss mechanical watch costing 200 times its more reliable quartz counterpart. But telling time is not the objective; signalling wealth is. And gift giving brings its own nuances (Carmichael and Macleod, 1997): it should be expensive (so as to insure it is not being distributed to any and all prospects) but useless (so that whatever delight is expressed by the recipient does not merely emanate from the usefulness of the object).

The ability to impress prospective mates enough to secure a mate, is de facto a matter of evolutionary life and death. Hence, status competition is expected to be a key driving force behind a host of economic decisions (Frank, 2011).

However, as with preferences for intra-generational resource transfers, the potential counteracting effects of culture should not be underestimated. Thus, although evolutionary theory suggests that males should be more status-seeking than women, a recent study by Gneezy, Leonard, and List (2009) finds that men tend to be more competitive in a patriarchial society (the Maasi of Tanzania), just as Western experiments indicate, while women were found to be more competitive in a matrilineal society (the Khasi of India). 


\section{Family Businesses}

Family businesses are common, even among large firms. Family connections are evident in the ownership and control of large privately held firms such as Fidelity Investments and Walmart. The familial element is especially large in some countries. For instance, among the 20 largest firms in Hong Kong, 14 had a family stake of at least one-fifth. But countries vary; in Japan only one of the top 20 had a family stake that large (Bertrand and Schoar, 2006). Nevertheless, the family element in business is substantial.

These trends need not have anything to do with relatedness or altruism per se. Bertrand and Schoar (2006) cite several rationales for family businesses that are not directly related to Hamilton's Rule. For example, a son or daughter might learn the business from an early age and possess knowledge that is difficult for a non-family member to match. Family members have inside knowledge about relatives' temperament and capabilities.

Yet there is some evidence that the forces of Hamilton's Rule can impede profit maximization. For instance, An Wang, founder of once successful computer company Wang Labs, appointed his son successor over far better qualified candidates, prompting the company's decline and eventual bankruptcy. More systematically, Perez-Gonzalez (2006) finds that firms whose incoming CEO's are related to the outgoing $\mathrm{CEO}$, the founder, or a large shareholder tend to underperform relative to those for whose CEO's are succeeded by non-relatives. The evidence is consistent with wasteful nepotism.

\section{Marriage Systems: Evolutionary Theory, Neuro-Biological Evidence, an Empirical Puzzle, and a Novel Hypothesis}

What explains differences in marriage-related norms around the world and over history? A welldeveloped social science literature has grown up around these questions, but they are not 
considered settled. In this section, it is argued that economists may achieve a fuller understanding of variation across time and space by using insights from evolutionary anthropology and biology.

In a sexually reproducing species like Homo sapiens, the production of each offspring requires exactly one man and one woman. ${ }^{13}$ Nonetheless, the fact that each human being typically produces more than one child on average (and must have done so in the past-otherwise our species would long ago have gone extinct), and that the human species is characterized by longlasting pair bonds between men and women, ${ }^{14}$ opens the door to a multitude of mating and living arrangements. The most common ones are life-long monogamy, serial monogamy, polygyny, and single motherhood; polyandry and group marriage also appear in some societies, although they are uncommon (Starkweather and Hames, 2012). ${ }^{15}$

Mating and living arrangements have been regulated for several thousands of years at least, as witnessed by the detailed rules on marriage and divorce, the handling of dowries, and adultery in the Code of Hammurabi, the oldest written account of laws and norms. Patterns in marriage systems are neither fully static across time, nor homogenous across space, however, as shown already by Westermarck (1891). Nowadays polygyny is still legal in many countries in West Africa for example, but not in, say, North America (Zeitzen, 2008). Divorce is vanishingly rare in India but not in Western Europe. In ancient Greece, either spouse could divorce at any time; early Christianity ushered in the prohibition of divorce.

More recently, in many developed countries marriage rates have declined while divorce and cohabitation rates have climbed. An intriguing and not yet fully understood pattern in the U.S. over the past few decades is that the decline in marriage has been concentrated in lower socioeconomic groups (Lundberg, Pollak, and Stearns, 2016). Based on the review below of the theoretical literature on the evolution of marriage systems ${ }^{16}$ and of some evidence on the neurobiology of mating, a novel hypothesis is proposed to help explain this empirical puzzle. The 
hypothesis is that preferences for commitment may (partly) explain both educational and marital outcomes.

\section{Marriage in our Evolutionary Past}

Theoretical models of the evolution of preferences and institutions such as marriage typically take the environment in which the population at hand evolves to be stable over time, where the environment is the set of factors that dictate the fitness consequences of behaviours, including mating arrangements. The reader is therefore invited to focus on pre-industrial times while reading the overview. The potential implications of this theory for modern societies will be discussed later.

The review below will sometimes refer to the "environment". In pre-industrial times, when the bulk of human populations consisted of self-sustaining households living in groups, many environmental factors - such as weather conditions, soil quality, ease of access to water, access to draught animals, the prevalence of human predators, and so on-indeed had important fitness consequences. The environment may thus have mattered for the relative fitness advantage or disadvantage of each marriage system, as will be discussed below.

\section{The Sex Ratio in the Marriage Market}

Intuitively, the sex ratio in the marriage market should be of first-order importance for whether men end up marrying several women or vice versa, since it determines both the supply and the demand for each sex. Ceteris paribus, skewed sex ratios should thus favour either polygyny or polyandry, depending on which sex is oversupplied (Starkweather and Hames, 2012). Many factors may lead up to skewed sex ratios in marriage markets. They may come about naturally as the result of sex-biased mortality rates in childhood and adolescence. They may arise because of selective abortions due to a preference for daughters or sons (Edlund, 1999). They can also be the 
result of population growth combined with a preference of men for younger women (Tertilt, 2005).

However, marriage norms typically do not change from generation to generation, depending on the sex ratio; to wit, the shortage of women in China has not led to polyandry, and the shortage of men in Europe following the two world wars did not lead to the legalisation of polygyny. ${ }^{17}$ Moreover, in theory skewed sex ratios should not be sustainable over long periods of time (Fisher, 1930). Finally, for most of its evolutionary past, the human population did not grow in size. Hence, while the sex ratio in any given generation should matter for the share of unmarried adults and divorce frequency in that generation, systematically skewed sex ratios are not believed to have played a major role in shaping marriage systems in the past. The literature has instead mainly focused on factors which tend to be more stable across generations.

\section{Heterogeneity Among Men and Among Women}

A key variable in the literature on marriage systems is heterogeneity among men. The idea that women may prefer to share a "high-quality" husband to monopolizing a "low-quality" one, leads to the conclusion that polygyny should be favoured in environments where there is heterogeneity among men in some dimension that matters for women's reproductive success. This prediction has been put forward not only by evolutionary biologists, who focus on male quality in the form of good genes (Bateman, 1948), but also by economists, who typically interpret male quality in pecuniary terms (Becker, 1974, Grossbard, 1986, Bergstrom, 1994a, 1994b). ${ }^{18}$ In particular, then, polygyny should be favoured in environments where men may accumulate wealth (Murdock, 1949). The advent of agriculture, with the ensuing ability to store wealth, notably in the form of domesticated animals, is thus believed to have entailed a major shift from egalitarianism to 
wealth inequality (Kohler et al., 2017), and therefore also from monogamous relationships (either life-long or serial) to the prevalence of polygynous ones.

Static models of the latter sort miss an important point, however: polygynous marriages dilute pecuniary wealth. Models that disregard wealth dynamics may thus overestimate the evolutionary advantage that polygyny confers on wealthy men; see Lagerlöf (2005), Fortunato and Archetti (2010), and Delacroix and Mariani (2015). ${ }^{19}$

The same criticism applies to analyses that disregard heterogeneity among women: under female heterogeneity, a man faces a quantity-quality trade-off, which may induce him to prefer monogamous to polygynous marriage. Such heterogeneity may be traced to differences in productivity (Grossbard, 1980), in human capital (Gould et al., 2008), in degree of faithfulness (Fortunato and Archetti, 2010, Gavrilets, 2012), or in the amount of wealth the woman brings to the household with her dowry (Goody, 1976).

Taken together, these theories predict that the prevalence of monogamy-as opposed to polygyny — should go hand in hand with economic and societal development. Historical evidence lends support to this prediction: monogamy was imposed by law in early Mesopotamia (Postgate, 1992), and both strict and serial monogamy were common in ancient Greece and Rome (Scheidel, 2008) (although in these societies a man could typically also have slave girls). And while polygynous marriage is still legal (at least for parts of the population) in about forty countries (Zeitzen, 2008), most marriages are monogamous (United Nations Department of Economic and Social Affairs, 2011).

\section{Production Technology}

When men can accumulate wealth, and some are better at it than others, inequality will emerge and marriage markets will likely be affected. Male productivity in turn depends on the production 
technology at hand. Technologies which enhance male productivity — such as the plough — are thus hypothesized to have favoured polygyny, conditional on land being accessible enough for the countervailing force of wealth dilution not to dominate (Boserup, 1970, Becker, 1974). However, other aspects related to production technology may also matter.

First, life-long monogamy should be favoured over serial monogamy in environments where serial monogamy would engender strong incentives for men to free-ride on each other's supply of goods to their common mates, as shown by Francesconi, Ghiglino, and Perry (2016). Arguably, an agricultural society in which men tend separate plots fits this description. However, in huntergatherer societies where men hunt big game together, it may be that serial monogamy would instead engender incentives for men to join forces in producing goods to their common mates. While the authors do not consider this possibility, doing so should lead to the conclusion that in such environments serial monogamy should be favoured over life-long monogamy. This theory could shed new light on the fact that both life-long and serial monogamy has been observed in hunter-gatherer populations (see, e.g., Fisher, 2011).

Second, in the evolutionary past the environment dictated the marginal returns to male and female efforts in food and care production. For instance, compare a hunter-gatherer population living in the Savannah rife with big game to one living in a small island in the Pacific surrounded by waters rich in fish. In the former, protein could essentially only be brought back to the family by men, given the incompatibility of hunting big game and nursing crying babies. By contrast, in the latter women could bring protein back to the family. Such environmental factors were likely key determinants for the quantity-quality trade-off that men faced in the evolutionary past when choosing between monogamous and polygynous marriage. As a result, male preferences over polygyny rates may have depended on the environment in which the population evolved (Alger, 2016). ${ }^{20}$ This result in turn implies that heterogeneity in male wealth may be a consequence rather than a cause of male preferences for polygynous marriage. To see this, compare two 
societies, one of which evolved in an environment with a less severe quantity-quality trade-off than the other. If the discrepancy is so large that men prefer polygyny over monogamy in the former society, and monogamy over polygyny in the latter, then men should also be more willing to compete against each other in the former than in the latter society. More competitive males may in turn result in greater heterogeneity in male wealth.

\section{Implications for Today's Societies}

Profound technological and societal transitions have taken place since the industrial revolution. So to what extent are evolutionary theories useful when it comes to understanding today's societies? Answering this question requires knowledge about the speed at which evolutionary forces operate; this speed may in turn depend on whether marriage systems are driven only by cultural factors, or whether biology is also relevant. Recent research has revealed some intriguing links between biological factors and marital outcomes. Some of this evidence is reviewed here, and its potential implications for today's societies are then discussed.

\section{On the Neuro-biology of Marital Outcomes}

Could biologically driven preferences be implicated in the empirical puzzle described by Lundberg, Pollak, and Stearns (2016), namely, the uneven decline in marriage by education? Economists usually refrain from invoking preferences to explain things, since doing so within the standard framework can be completely ad hoc. Preferences can be just about anything, meaning that just about anything can be explained by appealing to them. However, if preferences tied to survival and reproduction are transmitted from one generation to the next, evolutionary logic structures and explains them. In sum, when preferences are derived endogenously and examined empirically, invoking a preference-based explanation is anything but ad hoc. 
In view of the evolutionary theory, and especially the fact that monogamy is a rarity among mammals, it thus seems is reasonable to ask whether there is a "monogamy gene". The first answer to this question was given by studies comparing genetically close but behaviourally distinct vole species - the montane vole, the meadow vole, and the prairie vole. While male prairie voles mate for life and care for and defend offspring, male montane and meadow voles are promiscuous and rarely engage in parenting. The comparative studies centre on the neuropeptide arginine vasopressin (AVP), known to be associated with male social behaviours. When examining the neuroanatomical features of AVP receptors, Winslow et al. (1993) found that they were markedly different in the monogamous and the non-monogamous vole species. Young et al. (1999) then detected discrepancies between the structure of the AVP receptor gene (avprla) in prairie voles and that in meadow voles. Furthermore, when the AVP receptor gene of the prairie vole was transferred to the meadow vole, the latter began exhibiting the monogamous behaviour of its monogamous counterpart.

These findings in turn inspired examination of the human analogue of the AVP receptor gene in voles. Based on genetic and survey data collected in Sweden, Walum et al. (2008) observe that a particular sequence of the avprla gene is correlated with several measures of pair-bonding in men. In particular, an allele called 334 was found to play a role. Compared to men with zero copies of allele 334 in the said gene sequence, men with at least one copy of it scored significantly lower on a self-reported as well as a partner-reported pair-bonding scale, were less likely to be married to the partner as opposed to cohabiting with the partner and were more prone to experience marital discord. Moreover, the scores were significantly worse for men with two copies of allele 334 than for men with only one copy.

Besides vasopressin, testosterone (T) has also been found to be associated with men's mating behaviours. Using data collected on servicemen in the U.S. Army, Booth and Dabbs (1993) detected correlations between $\mathrm{T}$ levels on the one hand, and propensity to remain unmarried, to 
divorce, to physically abuse the spouse, and to engage in extra-marital sex on the other hand. Similar correlations were found in other sampled populations, including men in an American metropolitan area (Gray et al., 2002), and polygynous agriculturalists in rural Senegal (Alvergne, Faurie, and Raymond, 2009), where polygynous men were found to have significantly higher Tlevels than monogamous ones. The analysis of panel data on servicemen in the U.S. Air Force, Mazur and Michalek (1998) confirmed these correlations and further revealed that changes in marital status are associated with changes in T levels. More recently, Gettler et al. (2017) sought to identify links between variants of the androgen receptor (AR) gene and behaviours related to pair bonding. They found that men with the highest and those with the lowest levels of androgenicity (high $\mathrm{T}$ levels and gene variants which have been found to lead to more aggressive and more competitive behaviours in men) were significantly less likely than those with intermediate levels to experience relationship stability and invested fathering. The authors hypothesize that the non-monotonicity is due to different mechanisms for high and low androgenicity men: for the former, relationship problems would arise due to a higher interest in novel relationships, while for the latter, they would be due to a higher propensity of such men to be depressed.

\section{Preference Distributions Inherited From our Ancestors}

The evidence reviewed in the preceding subsection suggests that biology matters for the stability of pair bonds. ${ }^{21}$ Combined with evolutionary theory, which predicts that the distribution of biologically transmitted traits in a population should reflect its evolutionary past, this leads to an intriguing conjecture: in any given population today, the distribution of preferences for longlasting pair bonds may still reflect the environment in which the population evolved. 
Homo sapiens has for tens of thousands of years inhabited a wide variety of environments. The characteristics of each environment - such as the prevalence of predators and parasites, the climate, the quality of the soil, the geography, the ease of access to fresh water, the type of game present in the area-affect the survival value of many behaviours, including mating and living arrangements. That polygyny has occurred mostly in agricultural societies where men accumulate unequal wealth (Goody, 1976), and polyandry in places so rough that it takes two husbands to have a go at forming a household, ${ }^{22}$ are just two examples that lend credibility to the hypothesis that marriage systems adapt to the environment. ${ }^{23}$ Current distributions of deep-seated preferences for stable pair-bonds may thus be expected to reflect the past environment.

Taken together, the elements discussed so far in this section lead to the conclusion that economists would likely benefit from paying more attention to these preferences. The argument is illustrated in detail with a case study.

\section{Case Study: The Recent Decline of Marriage in the U.S.}

\section{An Empirical Puzzle}

In a recent overview, Lundberg, Pollak, and Stearns (2016) show that the evolution of rates of marriage, couple cohabitation, and childbearing in the U.S. over the decades following World War II exhibits the following patterns: (1) marriage rates fell and cohabitation rates rose substantially; (2) divorce rates doubled between the mid-1960's and the mid-1970's; (3) the proportion of births to unmarried women rose from 5\% in 1960 to $32 \%$ in 1995.

These changes may well be in line with the economic model of marriage developed by Gary Becker $(1973,1991)$, which centres on the idea that marriage is a contract that enables a man and a woman to produce "marital surplus" through a long-term exchange of labour income for household services. This model indeed predicts that marriage should become less common as this 
marital surplus declines, which it arguably did during this period, because of a rise of female labour market participation and falling fertility. Furthermore, many states adopted laws that rendered divorce less costly (see Lundberg, Pollak, and Stearns, 2016, for a detailed discussion).

The puzzle, however, is that the said changes were not uniform across socio-economic groups. In particular, the retreat from marriage - both in the form of divorce and in the form of cohabitation in lieu of marriage - as well as the rise in childbearing by non-married couples, were substantially more pronounced for individuals with a high school or a two-year college diploma than for individuals with a four-year college diploma. Lundberg, Pollak, and Stearns (2016) review the hypotheses that have been put forward to explain this pattern.

First, it has been argued that over this time period the share of "marriageable men" (i.e., good enough providers) declined faster in low than in high SES groups. While this hypothesis seems to be valid for the most disadvantaged groups (Edin and Nelson, 2013), it does not seem to hold for men with a high school or a two-year college degree.

Second, the fall in the wage gap between men and women may be perceived as a threat to gender identity. Since gender identity norms are stronger in lower SES groups (Davis and Greenstein, 2009), the fall in the wage gap may contribute to lower marriage rates and/or divorce in lower SES groups. This is what Bertrand, Kamenica, and Pan (2015) find in a study which compares individuals with a high-school degree of less with individuals with a college degree or more. It remains to be seen, however, whether gender identity norms are sufficiently different between high-school, two-year and four-year college graduates for the fall in the wage gap to be a force behind the observed patterns reported by Lundberg, Pollak, and Stearns (2016). Moreover, in a model that disregards gender identity issues, Barham, Devlin, and Yang (2009) predict that a reduction in the wage gap between the spouses should lead to an increase in marriage stability, under plausible assumptions. The reason is that a reduction in the wage gap leads the wife to specialize less and the husband to specialize more in household work; by making the public good 
produced in the household more efficient, this diminishes the value of being divorced for both spouses.

Third, the observed patterns could perhaps be explained by a fall in the ability of men and women to agree on a long-term contract, if this fall was more pronounced for individuals with a four-year college degree than for those with a two-year college degree or a high school diploma. Interestingly, this hypothesis led the federal government to launch the Healthy Marriage Initiative in 2003, an intervention aimed at improving relationship skills for low-income couples. It seems that, on average, this program was ineffective, although it sometimes had positive and sometimes negative effects (Wood et al., 2012). Using data on cognitive and non-cognitive skills collected through the National Longitudinal Study of Adolescent Health, Lundberg (2015) attributes this failure to the lack of explanatory power of such skills for relationship outcomes once education is controlled for.

Finally, a potentially relevant factor is the value of investment in children's human capital, a value which increased over the time period at hand, thus bolstering marital surplus (ceteris paribus). If, moreover, parents' investments are complementary and marriage is assortative with respect to education, then the incentive to invest in own education should have increased over this time period. This is precisely what Chiappori, Salanié, and Weiss (2017) find, both as a theoretical prediction in their model with endogenous investment in children and endogenous matching in the marriage market, and in the empirical estimation of the evolution of the marital college premium across the cohorts born between 1940 and 1970. This factor thus appears to be a relevant explanatory factor for the empirical puzzle reported by Lundberg, Pollak, and Stearns (2016).

In sum, while some factors appear to help explain the empirical puzzle described by Lundberg, Pollak, and Stearns (2016), there is arguably room to believe that other factors may have played a significant role. Preferences for commitment may be one of them. 


\section{The Elephant in the Room: Preferences}

Notwithstanding the rich set of variables that have been examined by economists to explain patterns in marriage markets, further progress could arguably be made if more attention was devoted to preferences in this domain. In economics models of marriage markets, an adult is typically taken to care about own consumption, children's welfare, and sometimes also the consumption utility of his or her partner(s). However, preferences do not depend directly on the particular form of the pair-bond(s) that the individual engages in. Both the theoretical and the empirical research on the biological basis of preferences indicates that this is restrictive.

Specifically, ceteris paribus, both an individual's educational attainment and his/her ability to enter and sustain a committed relationship may partly hinge on preferences whereby the individuals attaches a value to making long-term commitments. In other words, the correlation between educational attainment and marital outcome (the decision to get married rather than to just cohabit with the partner, and the propensity to remain married) described by Lundberg, Pollak, and Stearns (2016) is perhaps (partly) due to education and marriage outcomes being driven by the same preferences, combined with heterogeneity in these preferences in the population. ${ }^{24}$ In view of the neuro-biological evidence, these preferences may even be partly biologically determined.

This argument leads to a yet unexplored hypothesis to explain the data: once the cost of divorcing and cohabiting in lieu of marrying and remaining married fell after World War II, through a reduction both in social stigma and in direct costs, individuals with a weak intrinsic preference for commitment were more likely than individuals with a strong such preference to choose to either remain unmarried or engage in serial monogamy. 
Patterns in divorce rates during this period may thus be revealing. While George Axelrod suggested that humans are prone to a "seven-year itch" in his famous play-i.e., to an increased attraction to mates other than the spouse after seven years of marriage-Helen Fisher showed that on average divorce rates peak at four years following marriage (Fisher, 2016), although there are heterogeneities both within and between the populations she studied. Interestingly, in traditional societies women tend to space births by three to four years, by nursing their children for about three years. Hence, Fisher (2016) does not exclude that an "itch" of four years may be compatible with evolution.

While much more research is needed to reach a full understanding of these issues, evolutionary logic combined with neuro-biological evidence makes it hard to escape the hypothesis that preferences for commitment may be an explanatory variable of first-order importance when it comes to understanding marital outcomes. Arguably, omitting this variable may lead to misleading conclusions, from both a positive and a normative perspective.

\section{Nature and nurture}

Imagine a world where couples do not survive beyond the initial sexual encounter, and where children are cared for by their mothers or groups of women including their mothers, while men roam around in search for food and casual sex..$^{25}$ This imaginary world reveals how central the family — or at least the general tendency for both parents to cohabit with their young children-is to human societies, and by extension to the economy.

Different disciplines focus on different forces behind behaviours. For economists, the focus is on how individuals respond (in real time) to market conditions and changes therein, although in some economic models also laws and/or cultural norms-which individuals view as given when making their choices - to be endogenous. For biologists, while individual behavioural 
(phenotypic) plasticity is often taken into account, the focus instead is on the adaptation that occurs by way of changes in genotype distributions across generations.

There is a longstanding presumption that biological and environmental forces represent alternatives, captured by the familiar expression, "nature versus nurture." This framework might make sense if, for instance, we are interested in testing whether the gender pay gap is mostly driven by biologically based preferences for investing in children versus employer discrimination. But more recent evolutionary thinking has illuminated alternatives to the natureversus-nurture template.

A common characterization is that biology acts in concert with environmental and cultural forces. For instance, a toddler's brain is primed to absorb language, but for this to happen, the child has to hear speech. It is nonsensical to ask whether biology versus environment contributes more to language acquisition. Both are essential. Parsing nature from nurture in this example would be like trying to measure the sound of one hand clapping.

Indeed, attempts to distinguish nature from nurture have become even dicier with the emerging science of epigenetics, which studies how environmental changes themselves can affect how genes are expressed. There is evidence, for example, that during the Dutch Hunger Famine of 1944, unborn children of malnourished mothers underwent permanent changes in how certain of their genes were expressed, leading to lifelong health problems such as obesity (Tobi, et al, 2014). The dependence of genetic effects on environment via epigenetics makes it difficult if not impossible to classify outcomes that are driven by nature versus nurture.

An alternative way to think about biology and environment would be to consider that, while biological attributes might predispose certain behaviours, the environmental landscape is what 
shapes the way these proclivities play out. Someone may be genetically predisposed to obesity yet never become overweight for a variety of non-biological reasons: fattening food is expensive or inaccessible (economics, environment), or the person has come to believe in the importance of diet and exercise (culture). Personal choice can override predispositions. Biology is not destiny. But it is a useful complement to economics.

Economists tend to focus on how variations in prices (and sometimes laws and cultural norms) affect people's choices with preferences usually taken as given. Biologists on the other hand are concerned with how preferences evolved--the adaptation arising via changes in genotype distributions across generations. Given the central role that behaviours in the realm of the family have played in the evolutionary race for survival and reproduction ever since our ancestors started to live in families, they may in turn be expected to have been subject to severe evolutionary selection. Evolutionary biologists and anthropologists would therefore view the distribution of family-related behaviours as responses to this selection.

Could the evolutionary approach be a useful complement to the traditional economics approach? Arguably, an even stronger case can be made, namely, that disregarding this approach may prompt economists to draw misleading conclusions from their analyses. Evolutionary theory together with recent evidence on biological behavioural triggers, such as hormones, neurotransmitters, and genes, leads to the hypothesis that current preference distributions may be a reflection of our evolutionary past. Economic analyses that do not acknowledge this hypothesis, by focusing solely on cultural forces, may deliver ineffective policy recommendations. The full complexity of the human family, in particular the interplay between nature and nurture, is far from well understood, and we contend that economists can play an important role in making progress in this area. 


\section{Further Reading}

Hrdy, Sarah B. (2011) Mother Nature. Cambridge, MA: Harvard University Press.

Ridley, Matt (1994) The Red Queen. New York, Macmillan Pub. Co.

Seabright, Paul. (2012) The War of the Sexes. Princeton NJ: Princeton University Press.

Wright, Robert (1994) The Moral Animal. New York NY: Random House. 


\section{References}

Alexander, R. D. (1974). The evolution of social behavior. Annual Review of Ecology and Systematics, 5, 325-383.

Alger, I. (2016). How many wives do men want? On the evolution of polygyny rates. Working Paper 15-586, Toulouse School of Economics.

Alger, I. \& Cox, D. (2013). The evolution of altruistic preferences: mothers versus fathers. Review of Economics of the Household, 11, 421-446.

Alger, I. \& Weibull, J. W. (2010). Kinship, incentives, and evolution. American Economic Review, 100, 1725-1758.

Alger, I., Weibull, J. W. \& Lehmann, L. (2018). Evolution of preferences in group-structured populations: Genes, guns, and culture. Working Paper 18-888, Toulouse School of Economics.

Alvergne, A., Faurie, C. \& Raymond, M. (2009). Variation in testosterone levels and male reproductive effort: Insight from a polygynous human population. Hormones and Behavior, $56,491-497$.

Anderson, K. G. (2006). How well does paternity confidence match actual paternity? evidence from worldwide non-paternity rates. Current Anthropology, 47, 513-520.

Anderson, K. G., Kaplan, H. \& Lancaster, J. B. (2007). Confidence of paternity, divorce, and investment in children by Albuquerque men. Evolution and Human Behavior, 28, $1-10$.

Angrist, J. (2002). How do sex ratios affect marriage and labor markets? Evidence from America's second generation. Quarterly Journal of Economics, 117, 997-1038.

Balaresque, P., Poulet, N., Cussat-Blanc, S., Gerard, P., Quintana-Murci, L., Heyer, E. \& Jobling, M. (2015). Y-chromosome descent clusters and male differential reproductive success: 
young lineage expansions dominate Asian pastoral nomadic populations. European Journal of Human Genetics, 23, 1413-1422.

Barham, V., Devlin, R. A. \& Yang, J. (2009). A theory of rational marriage and divorce. European Economic Review, 53, 93 - 106.

Bateman, A. J. (1948). Intra-sexual selection in Drosphilia. Heredity, 2, 277-287.

Becker, G. S. (1973). A theory of marriage: Part I. Journal of Political Economy, 81, 813-846.

Becker, G. S. (1974). A theory of marriage: Part II. Journal of Political Economy, 82, S11-S26.

Becker, G. S. (1991). A Treatise on the Family (2 ${ }^{\text {nd }}$ ed.). Cambridge, MA: Harvard University Press.

Becker, G. S. \& Lewis, H. G. (1973). On the interaction between the quantity and quality of children. Journal of Political Economy, 81, S279-S288.

BenYishay, A., Grosjean, P. \& Vecci, J. (2017). The fish is the friend of matriliny: Reef density and matrilineal inheritance. Journal of Development Economics, 127, 234 - 249.

Bergstrom, T. C. (1994a). On the economics of polygyny. Working paper, University of Michigan.

Bergstrom, T. C. (1994b). Primogeniture, monogamy, and reproductive success in a stratified society. Working paper, University of Michigan.

Bergstrom, T. C. (1995). On the evolution of altruistic ethical rules for siblings. American Economic Review, 85, 58-81.

Bergstrom, T. C. (1996). Economics in a family way. Journal of Economic Literature, 34, 19031934.

Bernhardt, A., Field, E., Pande, R., Rigol, N., Schaner, S. \& Troyer-Moore, C. (2018). Male social status and women's work. AEA Papers and Proceedings, 108, 363-367.

Bertrand, M., Kamenica, E. \& Pan, J. (2015). Gender identity and relative income within households. Quarterly Journal of Economics, 130, 571-614. 
Bertrand, M. \& Schoar, A. (2006). The role of family in family firms. Journal of Economic Perspectives, 20, $73-96$.

Bethmann, D. \& Kvasnicka, M. (2011). The institution of marriage. Journal of Population Economics, 24, 1005-1032.

Bethmann, D. \& Kvasnicka, M. (2013). World War II, missing men and out of wedlock childbearing. Economic Journal, 123, 162-194.

Betzig, L. (1995). Medieval monogamy. Journal of Family History, 20, 181-216.

Booth, A. \& Dabbs, J. M. (1993). Testosterone and men's marriages. Social Forces, 72, 463-477.

Boserup, E. (1970). Woman's Role in Economic Development. New York, NY: St Martins Press.

Buss, D. (1989). Sex differences in human mate preferences: Evolutionary hypotheses tested in 37 cultures. Behavioral and Brain Sciences, 12, 1-49.

Buss, D. M. (2002). Human mate guarding. Neuroendocrinology Letters, 23, 23 - 29.

Buss, D. M., Larsen, R. J., Westen, D. \& Semmelroth, J. (1992). Sex differences in jealousy: Evolution, physiology, and psychology. Psychological Science, 3, 251 - 255.

Carmichael, H. L. \& MacLeod, W. B. (1997). Gift Giving and the Evolution of Cooperation. International Economic Review, 38, 485--509.

Chiappori, P.-A., Salanié, B. \& Weiss, Y. (2017). Partner choice, investment in children, and the marital college premium. American Economic Review, 107, 2109-2167.

Cigno, A., Komura, M. \& Luporini, A. (2017). Self-enforcing family rules, marriage and the (non)neutrality of public intervention. Journal of Population Economics, 30, 805-834.

Cox, D. (2004). Private interhousehold transfers in Vietnam in the early and late 1990s. In P. Glewwe, N. Agrawal \& D. Dollar (Eds.), Economic Growth, Poverty and Household Welfare in Vietnam (pp. 567-603). Washington, DC: The World Bank.

Cox, D. (2007). Biological basics and the economics of the family. Journal of Economic Perspectives, 21, 91-108. 
Croson, R. \& Gneezy, U. (2009). Gender differences in preferences. Journal of Economic Literature, 47, 448-474.

Davis, S. N. \& Greenstein, T. N. (2009). Gender ideology: Components, predictors, and consequences. Annual Review of Sociology, 35, 87-105.

De la Croix, D. \& Mariani, F. (2015). From polygyny to serial monogamy: A unified theory of marriage institutions. Review of Economic Studies, 82, 565 - 607.

Diamond, J. (1997). Why is Sex Fun?: The Evolution of Human Sexuality. New York, NY: Basic Books.

Duflo, E. (2003). Grandmothers and granddaughters: Old-age pensions and intrahousehold allocation in South Africa. World Bank Economic Review, 17, 1-25.

Duflo, E. (2012). Women empowerment and economic development. Journal of Economic Literature, 50, 1051-1079.

Eaton, C. \& Eswaran, M. (2003). The evolution of preferences and competition: a rationalization of Veblen's theory of invidious comparisons. Canadian Journal of Economics, 36, 832-859.

Edin, K. \& Nelson, T. J. (2013). Doing the Best I Can: Fatherhood in the Inner City. Berkeley, CA: University of California Press.

Edlund, L. (1999). Son preference, sex ratios, and marriage patterns. Journal of Political Economy, 107, 1275 - 1304.

Edlund, L. (2018). Cousin marriage is not choice: Muslim marriage and underdevelopment. $A E A$ Papers and Proceedings, 108, 353-57.

Emlen, S. T. (1995). An evolutionary theory of the family. Proceedings of the National Academy of Sciences, 92, $8092-8099$.

Eswaran. M. \& Kotwal, A. (2004). A theory of gender differences in parental altruism. Canadian Journal of Economics, 37, 918-950. 
Fisher, H. (2011). Serial monogamy and clandestine adultery: Evolution and consequences of the dual human reproductive strategy. In S. Roberts (Ed.), Applied Evolutionary Psychology. Oxford: Oxford University press.

Fisher, H. (2016). Anatomy of Love (2 ${ }^{\text {nd }}$ ed.). New York, NY: W.W. Norton and co.

Fisher, R. A. (1930). The Genetical Theory of Natural Selection. Oxford: Oxford University Press.

Fisman, R., Iyengar, S. S., Kamenica, E. \& Simonson, I. (2006). Gender differences in mate selection: Evidence from a speed dating experiment. Quarterly Journal of Economics, 121, 673-697.

Fortunato, L. (2015). Marriage systems, evolution of. In J. D. Wright (Ed.), International Encyclopedia of the Social and Behavioral Sciences (2 ${ }^{\text {nd }}$ ed., pp. 611 - 619). Oxford: Elsevier.

Fortunato, L. \& Archetti, M. (2010). Evolution of monogamous marriage by maximization of inclusive fitness. Journal of Evolutionary Biology, 23, 149-156.

Fox, D. (2017). Reproductive negligence. Columbia Law Review, 117, 149-241.

Francesconi, M., Ghiglino, C. \& Perry, M. (2016). An evolutionary theory of monogamy. Journal of Economic Theory, 166, 605 - 628.

Frank, R. H. (2011). The Darwin Economy: Liberty, Competition, and the Common Good. Princeton: Princeton University Press.

Gavrilets, S. (2012). Human origins and the transition from promiscuity to pair-bonding. Proceedings of the National Academy of Sciences, 109, 9923-9928.

Geary, D. C., Vigil, J. \& Byrd-Craven, J. (2004). Evolution of human mate choice. Journal of Sex Research, 41, 27-42.

Gettler, L. T., Ryan, C. P., Eisenberg, D. T., Rzhetskaya, M., Hayes, M. G., Feranil, A. B., Bechayda, S. A. \& Kuzawa, C. W. (2017). The role of testosterone in coordinating male 
life history strategies: The moderating effects of the androgen receptor $\{\mathrm{CAG}\}$ repeat polymorphism. Hormones and Behavior, 87, $164-175$.

Gilby, I. C., Thompson, M. E., Ruane, J. D. \& Wrangham, R. (2010). No evidence of short-term exchange of meat for sex among chimpanzees. Journal of Human Evolution, 59, 44 - 53.

Gneezy, U., Leonard, K. L. \& List, J. A. (2009). Gender differences in competition: Evidence from a matrilineal and a patriarchal society. Econometrica, 77, 1637-1664.

Gomes, C. M. \& Boesch, C. (2009). Wild chimpanzees exchange meat for sex on a long-term basis. PLoS ONE, 4, e5116.

Goody, J. (1976). Production and Reproduction. Cambridge: Cambridge University Press.

Gould, E. D., Moav, O. \& Simhon, A. (2008). The mystery of monogamy. American Economic Review, 98, 333-57.

Gray, J. (1998). Ethnographic atlas codebook derived from George P. Murdock's ethnographic atlas recording the marital composition of 1231 societies from 1960 to 1980. World Cultures, 10, 86-136.

Gray, P. B., Kahlenberg, S. M., Barrett, E. S., Lipson, S. F. \& Ellison, P. T. (2002). Marriage and fatherhood are associated with lower testosterone in males. Evolution and Human Behavior, 23, 193-201.

Grosjean, P. \& Brooks, R. C. (2017). Persistent effect of sex ratios on relationship quality and life satisfaction. Philosophical Transactions of the Royal Society B: Biological Sciences, 372, 20160315.

Grosjean, P. \& Khattar, R. (2018). It's raining men! Hallelujah? The long-run consequences of male-biased sex ratios. Review of Economic Studies, p. rdy025.

Grossbard-Shechtman, A. (1980). The economics of polygamy. In J. DaVanzo \& J. Simon (Eds.), Research in Population Economics. Boulder, CO: JAI Press. 
Grossbard-Shechtman, A. (1986). Economic behavior, marriage and fertility: Two lessons from polygyny. Journal of Economic Behavior and Organization, 7, 415 - 424.

Hamilton, W. (1964). The genetical evolution of social behaviour. Journal of Theoretical Biology, 7, $1-52$.

Hartung, J., Abelson, A. E., Basu, A., Basu, M. P., Beals, K. L., Chiarelli, B., Curtain, C. C.,... Wood, C. S. (1976). On natural selection and the inheritance of wealth [and comments and reply]. Current Anthropology, 17, 607-622.

He, Q.-Q., Wu, J.-J., Ji, T., Tao, Y. \& Mace, R. (2016). Not leaving home: grandmothers and male dispersal in a duolocal human society. Behavioral ecology, 27, 1343-1352.

Hitsch, G. J., Hortaçsu, A. \& Ariely, D. (2010). What makes you click?-Mate preferences in online dating. Quantitative Marketing and Economics, 8, 393-427.

Kaplan, H. (1994). Evolutionary and wealth flows theories of fertility: Empirical tests and new models. Population and Development Review, 20, 753-791.

Kaplan, H., Hill, K., Lancaster, J. \& Hurtado, A. M. (2000). A theory of human life history evolution: Diet, intelligence, and longevity. Evolutionary Anthropology: Issues, News, and Reviews, 9, 156-185.

Kaplan, H. S., Hooper, P. L. \& Gurven, M. (2009). The evolutionary and ecological roots of human social organization. Philosophical Transactions: Biological Sciences, 364, 3289_ 3299.

Kappeler, P. M. \& van Schaik, C. P. (2002). Evolution of primate social systems. International Journal of Primatology, 23, 707-740.

Kelly, R. L. (2013). The Lifeways of Hunter-Gatherers (2 ${ }^{\text {nd }}$ ed.) Cambridge: Cambridge University Press.

Kleven, H., Landais, C. \& Sgaard, J. E. (2018). Children and gender inequality: Evidence from Denmark. Working Paper 24219, NBER. 
Kohler, T. A., Smith, M. E., Bogaard, A., Feinman, G. M., Peterson, C. E., Betzenhauser, A., Pailes, M.,... Bowles, S. (2017). Greater post-Neolithic wealth disparities in Eurasia than in North America and Mesoamerica. Nature, 551, 619 EP.

Kokko, H. \& Jennions, M. (2008). Parental investment, sexual selection and sex ratios. Journal of Evolutionary Biology, 21, 919-948.

Lagerlöf, N.-P. (2005). Sex, equality, and growth. Canadian Journal of Economics, 38, 807-831.

Lagerlöf, N.-P. (2010). Pacifying monogamy. Journal of Economic Growth, 15, 235-262.

Lee, R. \& Mason, A. (2011). Population Aging and the Generational Economy: A Global Perspective. Northampton, MA: Edward Elgar.

Lee, Y.-J., Parish, W. L. \& Willis, R. J. (1994). Sons, daughters, and intergenerational support in Taiwan. American Journal of Sociology, 99, 1010-1041.

Lundberg, S. (2015). Skill disparities and unequal family outcomes. Research in Labor Economics, 41, 177-212.

Lundberg, S. J., Pollak, R. A. \& Wales, T. J. (1997). Do husbands and wives pool their resources? Evidence from the United Kingdom child benefit. Journal of Human Resources, $32,463-480$.

Lundberg, S., Pollak, R. A. \& Stearns, J. (2016). Family inequality: Diverging patterns in marriage, cohabitation, and childbearing. Journal of Economic Perspectives, 30, 79-102.

Mazur, A. \& Michalek, J. (1998). Marriage, divorce, and male testosterone. Social Forces, 77, 315-330.

Miller, G. (2000). The Mating Mind: How Sexual Choice Shaped the Evolution of Human Nature. New York, NY: Doubleday.

Mischel, W., Ayduk, O., Berman, M. G., Casey, B. J., Gotlib, I. H., Jonides, J., Kross, E., ... Shoda, Y. (2011). Willpower over the life span: decomposing self-regulation. Social Cognitive and Affective Neuroscience, 6, 252-256. 
Murdock, G. P. (1949). Social Structure. New York, NY: The MacMillan Company.

Orians, G. H. (1969). On the evolution of mating systems in birds and mammals. American Naturalist, 103, 589-603.

Owen, G., Fulton, R. \& Markusen, E. (1983). Death at a distance: A study of family survivors. OMEGA - Journal of Death and Dying, 13, 191-225.

Perez-Gonzalez, F. (2006). Inherited control of firm performance. American Economic Review, $96,1559-1588$.

Perry, M., Reny, P. J. \& Robson, A. J. (2017). Why sex? and why only in pairs? Economic Journal, 127, 2730-2743.

Postgate, J. N. (1992). Early Mesopotamia: Society and Economy at the Dawn of History. London and Ney York: Routledge.

Rasteiro, R. \& Chikhi, L. (2013). Female and male perspectives on the Neolithic transition in Europe: Clues from ancient and modern genetic data. PLoS ONE, 8, e60944.

Rosenzweig, M. R. \& Wolpin, K. I. (1985). Specific experience, household structure, and intergenerational transfers: Farm family land and labor arrangements in developing countries. Quarterly Journal of Economics, 100, 961-987.

Ross, C. T., Borgerhoff Mulder , M., Oh, S.-Y., Bowles, S., Beheim, B., Bunce, J., Caudell , M., ... Ziker, J. (2018). Greater wealth inequality, less polygyny: rethinking the polygyny threshold model. Journal of The Royal Society Interface, 15.

Sanders, C. M. (1980). A comparison of adult bereavement in the death of a spouse, child, and parent. OMEGA - Journal of Death and Dying 10, 303-322.

Scheidel, W. (2008). Monogamy and polygyny in Greece, Rome, and world history. Working papers in classics, Princeton/Stanford.

Sear, R. \& Mace, R. (2008). Who keeps children alive? A review of the effects of kin on child survival. Evolution and Human Behavior, 29, 1 - 18. 
Starkweather, K. E. \& Hames, R. (2012). A survey of non-classical polyandry. Human Nature, $23,149-172$.

Tertilt, M. (2005). Polygyny, fertility, and savings. Journal of Political Economy, 113, 13411371.

Todd, E. (2011). L'origine des systèmes familiaux. Paris: Gallimard.

Trivers, R. L. (1972). Parental investment and sexual selection. In B. Campbell (Ed.), Sexual Selection and the Descent of Man (pp. 136-179). Chicago, IL: Aldine.

United Nations Department of Economic and Social Affairs (2011). Population facts, No. 2011/1, $\mathrm{UN}$.

Walum, H., Westberg, L., Henningsson, S., Neiderhiser, J. M., Reiss, D., Igl, W., Ganiban, J. M., ... Lichtenstein, P. (2008). Genetic variation in the vasopressin receptor la gene (avpr1a) associates with pair-bonding behavior in humans. Proceedings of the National Academy of Sciences, 105, 14153-14156.

Wei, S.-J. \& Zhang, X. (2011). The competitive saving motive: Evidence from rising sex ratios and savings rates in China. Journal of Political Economy, 119, 511-564.

Westermarck, E. (1891). The History of Human Marriage. New York, NY: Macmillan.

Willis, R. J. (1999). A theory of out-of-wedlock childbearing. Journal of Political Economy, 107, S33-S64.

Wing, C. C. K. (1995). Love thy parents and care for thy children: Filial piety and intergenerational cooperation in traditional China. Journal of Socio-Economics, 24, 391408.

Winslow, J. T., Hastings, N., Carter, C. S., Harbaugh, C. R. \& Insel, T. R. (1993). A role for central vasopressin in pair bonding in monogamous prairie voles. Nature, 365, $545-548$. 
Wood, R. G., McConnell, S., Moore, Q., Clarkwest, A. \& Hsueh, J. (2012). The effects of

building strong families: A healthy marriage and relationship skills education program for unmarried parents. Journal of Policy Analysis and Management, 31, 228-252.

Xiaoyan Lei, John Giles, Y. H. A. P. J. S. \& Zhao, Y. (2012). Patterns and Correlates of Intergenerational Nontime Transfers: Evidence from CHARLS. The National Academies Press, pp. $207-228$.

Young, L. J., Nilsen, R., Waymire, K. G., MacGregor, G. R. \& Insel, T. R. (1999). Increased affiliative response to vasopressin in mice expressing the vla receptor from a monogamous vole. Nature, 400, 766-768.

Zeitzen, M. K. (2008). Polygamy: A Cross-Cultural Analysis. Oxford: Berg Publishers.

\section{Notes}

\footnotetext{
${ }^{4}$ Between mother and child, for instance, $r=1 / 2$; so too between siblings. Between cousins $\quad r=1 / 8$ and between grandparent and grandchild, $r=1 / 4$.

${ }^{5}$ The difference between the left-hand side and the right-hand side of the inequality is the expected net fitness effect of the helping behavior at hand for carriers of a gene that triggers the helping behavior, when that gene is rare - this is called the "inclusive fitness effect". In essence, Hamilton's Rule simply says that a population in which the prevalent gene prompts behaviour that does not maximize inclusive fitness, can be invaded by a gene that prompts behaviour that yields a higher inclusive fitness.

${ }^{6}$ We here discuss Hamilton's rule the way it was originally cast-i.e., applied to biologically transmitted traits. Although culturally transmitted traits may be transmitted from individuals other than own parents, individuals who have inherited their trait from the same "cultural ancestor" can be said to be "related". In other words, Hamilton's rule also applies to culturally transmitted traits; for expositions of Hamilton's rule in economics, see Bergstrom (1995), Alger and Weibull (2010) and Alger, Weibull, and Lehmann (2018).

${ }^{7}$ That is, $r B=1.25>C=1$.

${ }^{8}$ See the discussion in Cox (2007).

${ }^{9}$ See also Cigno, Komura, and Luporini (2017).

${ }^{10}$ See, for example, Duflo (2012).

${ }^{11}$ For an extended summary of this evidence, see Alger and Cox (2013).

12 Though hospitals have been known to send couples home with the wrong baby, documented cases are rare (Fox, 2017).

${ }^{13}$ Not all species reproduce sexually. Some species, notably bacteria, use cloning, or asexual reproduction. In sexually reproducing species, the sex of an individual is either fixed throughout life or not, and there may be more than two sexes. On the long term evolutionary time scale, the fact that Homo sapiens is a sexually reproducing species with two distinct and fixed sexes is endogenous (see Perry, Reny, and Robson (2017) for a theoretical explanation). On the shorter evolutionary time scale and on the time scale of a human life, however, this fact is of course exogenous (although humanly devised technologies, such as sperm banks, can somewhat alter the technology).

${ }^{14}$ Interestingly, such long-lasting pair bonds are more common among avian species than among mammals; Orians (1969), Gilby et al. (2010), Gomes and Boesch (2009).
} 
${ }^{15}$ Obviously, even strict monogamy laws do not prevent men and women from engaging in extra-pair copulations (Betzig, 1995, Fisher, 2011). However, they may alter the fitness consequences of doing so, especially in societies where adultery is considered worthy of punishment by death.

${ }^{16}$ For a survey of the contributions in anthropology and biology, see Fortunato (2015).

${ }^{17}$ It seems, however, that heavily skewed sex ratios may have long-lasting effects on female labor supply (Grosjean and Khattar, 2018) and on marital satisfaction (Grosjean and Brooks, 2017).

${ }^{18}$ For a model with both rival and non-rival male wealth, see Ross et al. (2018).

${ }^{19}$ Ultimately, social unrest may even have prompted the ruling elite to propose a social contract with the ruled whereby monogamy was imposed on the elite (Lagerlöf, 2010).

${ }^{20}$ For compelling evidence that variation in the environment may matter for family-related behaviours, see BenYishay, Grosjean, and Vecchi (2017), who show that variation in coral reef density between locations in the Solomon Islands is a significant predictor of the variation in inheritance rules between these locations.

${ }^{21}$ For a more extensive review of the evidence, and for a broader discussion of pair-bonding in humans, see Fisher's (2016) fascinating book.

${ }^{22}$ Indeed, most polyandrous societies are located in the Himalayas; in such harsh environments men practicing polyandry may achieve a higher reproductive success than men practicing other mating arrangements (Alexander, 1974).

${ }^{23}$ In spite of massive migrations in the past, and in spite of the migration of individuals or small bands of individuals, large shares of many populations must have evolved for long periods of time in a fixed environment. Even huntergatherers, who unlike agriculturalists would not have been bound to any particular land property, migrate only small distances in their lifetime or resort mostly to seasonal migrations (Kelly, 2013).

${ }^{24}$ Relatedly, research based on the famous marshmallow test shows that individuals who, as small children, were better than others at delaying gratification, achieved better educational outcomes; future research will tell whether the behavior of young children in the marshmallow test recorded almost fifty years ago also predicts their marital outcomes (Mischel et al., 2011).

${ }^{25}$ Such a world is, however, common in the animal kingdom. In his cross-species comparison, Emlen (1995) defined a family as a case "where offspring continue to interact regularly, into adulthood, with their parents," and found that only a small percentage of the mammalian and avian species he studied, lived in families. 